\title{
Bradykinin and Nerve Growth Factor Play Pivotal Roles in Muscular Mechanical Hyperalgesia after Exercise (Delayed-Onset Muscle Soreness)
}

\author{
Shiori Murase, ${ }^{1}$ Etsuji Terazawa, ${ }^{1,2^{\dagger}}$ Fernando Queme, ${ }^{1}$ Hiroki Ota, ${ }^{1}$ Teru Matsuda, ${ }^{1}$ Kenji Hirate, ${ }^{3 \dagger \dagger}$ Yasuko Kozaki, ${ }^{1,4}$ \\ Kimiaki Katanosaka, ${ }^{1}$ Toru Taguchi, ${ }^{1}$ Hisako Urai, ${ }^{1,5}$ and Kazue Mizumura ${ }^{1}$ \\ ${ }^{1}$ Department of Neuroscience II, Research Institute of Environmental Medicine, Nagoya University, Nagoya 464-8601, Japan, ${ }^{2}$ Department of \\ Anesthesiology and Pain Medicine, Gifu University School of Medicine, Gifu 501-1194, Japan, ${ }^{3}$ Laboratory of Discovery Research, Research Laboratories, \\ Nippon Chemiphar Company, Ltd., Misato 341-0005, Japan, ${ }^{4}$ Department of Pharmacy, Kinjo Gakuin University, Nagoya 463-8521, Japan, and \\ ${ }^{5}$ Department of Sport and Health Sciences, Graduate School of Sport Sciences, Osaka University of Health and Sport Sciences, Osaka 590-0496, Japan
}

Unaccustomed strenuous exercise that includes lengthening contraction (LC) often causes delayed-onset muscle soreness (DOMS), a kind of muscular mechanical hyperalgesia. The substances that induce this phenomenon are largely unknown. Peculiarly, DOMS is not perceived during and shortly after exercise, but rather is first perceived after $\sim 1 \mathrm{~d}$. Using $\mathrm{B}_{2}$ bradykinin receptor antagonist HOE 140 , we show here that bradykinin released during exercise plays a pivotal role in triggering the process that leads to muscular mechanical hyperalgesia. HOE 140 completely suppressed the development of muscular mechanical hyperalgesia when injected before LC, but when injected $2 \mathrm{~d}$ after LC failed to reverse mechanical hyperalgesia that had already developed. $\mathrm{B}_{1}$ antagonist was ineffective, regardless of the timing of its injection. Upregulation of nerve growth factor (NGF) mRNA and protein occurred in exercised muscle over a comparable time course (12 h to $2 \mathrm{~d}$ after $\mathrm{LC}$ ) for muscle mechanical hyperalgesia. Antibodies to NGF injected intramuscularly $2 \mathrm{~d}$ after exercise reversed muscle mechanical hyperalgesia. HOE 140 inhibited the upregulation of NGF. In contrast, shortening contraction or stretching induced neither mechanical hyperalgesia nor NGF upregulation. Bradykinin together with shortening contraction, but not bradykinin alone, reproduced lasting mechanical hyperalgesia. We also showed that rat NGF sensitized thin-fiber afferents to mechanical stimulation in the periphery after 10-20 min. Thus, NGF upregulation through activation of $B_{2}$ bradykinin receptors is essential (though not satisfactory) to mechanical hyperalgesia after exercise. The present observations explain why DOMS occurs with a delay, and why lengthening contraction but not shortening contraction induces DOMS.

\section{Introduction}

Delayed-onset muscle soreness (DOMS) is described as unpleasant sensation or pain after unaccustomed strenuous exercise (Armstrong, 1984). DOMS is characterized by tenderness and movement-related pain, that is, mechanical hyperalgesia, in the exercised muscle. It usually reaches a peak 1-2 d after exercise in humans and disappears within 3-7 d (Armstrong, 1984; GravenNielsen and Arendt-Nielsen, 2003). It is not known why DOMS typically appears with some delay $(\sim 1 \mathrm{~d})$ rather than during and shortly after exercise, or why DOMS can be easily induced by

Received Aug. 4, 2009; revised Jan. 25, 2010; accepted Jan. 28, 2010.

This work was partly supported by a Grant-in-Aid for Scientific Research (B) from the Japan Society for the Promotion of Science (No. 18390069), by a grant from the Strategic International Cooperative Program, Japan Science and Technology Agency (JST), and by a research grant from the Uehara Memorial Foundation. S.M. was supported by the JST.

${ }^{\dagger}$ Deceased, July 13, 2006.

${ }^{\dagger \dagger}$ Deceased, Nov. 26, 2006.

The authors E. Terazawa and K. Hirate passed away from illness during the course of this experiment. The corresponding author expresses her condolences and dedicates this article to their important contributions.

Correspondence should be addressed to Kazue Mizumura, Department of Neuroscience II, Research Institute of Environmental Medicine, Nagoya University, Nagoya 464-8601, Japan. E-mail: mizu@riem.nagoya-u.ac.jp. D01:10.1523/JNEUROSCI.3803-09.2010

Copyright $\odot 2010$ the authors $\quad 0270-6474 / 10 / 303752-10 \$ 15.00 / 0$ lengthening contraction (LC; contraction while the muscle is being stretched, often called "eccentric contraction") but not by either shortening contraction (SC) or stretching. DOMS itself is a common and rather unremarkable event in daily life. However, since hyperalgesic muscle in this DOMS model is reported to contain taut band-like muscle hardening and a trigger point-like sensitive spot (Itoh and Kawakita, 2002; Itoh et al., 2004), which are typical in myofascial pain syndrome (Russell and Bieber, 2006), uncovering the mechanism of DOMS in this model may shed light on the peripheral mechanism of the muscular mechanical hyperalgesia that occurs in pathological conditions.

Several proposals have been made to explain the mechanism of DOMS based on histological, ultrastructural, and biochemical findings in both humans and animals. They include lactic acid, spasm, connective tissue damage, muscle damage, inflammation, and oxidative stress (Armstrong, 1984; Smith, 1991; Cheung et al., 2003). The most widely supported mechanisms are muscle damage and inflammation induced by it, but reports suggesting other causes are emerging (Malm et al., 2004; Crameri et al., 2007).

Many substances are released from exercising muscle: lactate (Tegeder et al., 2002); bradykinin (including kallidin-like pep- 


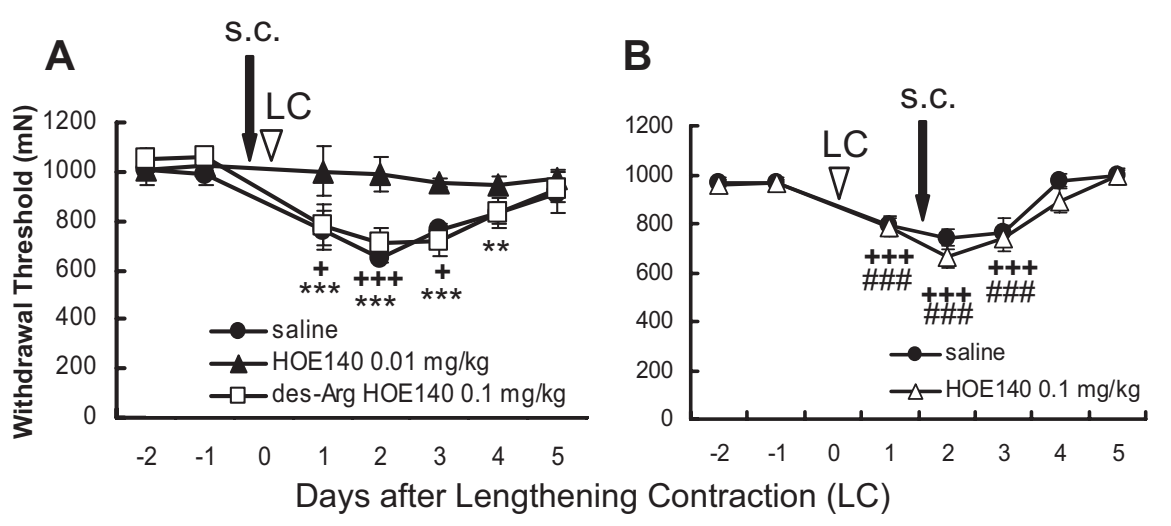

C

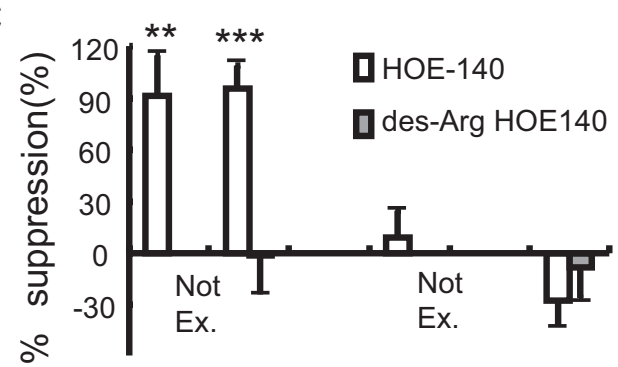

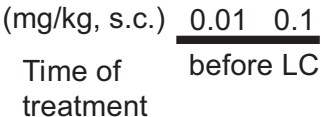

$\begin{array}{ll}\frac{0.1}{30 \min } & \frac{0.1}{2 \text { days }} \\ \text { aft. LC } & \text { aft. LC }\end{array}$

Figure 1. $B_{2}$, but not $B_{1}$, antagonist injected before exercise blocked development of muscle mechanical hyperalgesia. $A, B$, Decrease in the mechanical threshold of exercised muscle observed 1-3 d after LC (saline group, solid circle) was blocked by a $B_{2}$ antagonist, HOE 140, administered subcutaneously 30 min before LC (solid triangle in $A$ ), but not by injection 30 min before threshold measurement on the second day (open triangle in $B$ ). $A B_{1}$ antagonist, des- $-\operatorname{Arg}^{10}$-HOE 140 , had no effect (open square in $A$ ). Arrows and arrowheads, Time points for antagonist injection and LC loading (on day 0$)$, respectively. Mean \pm SEM ( $n=6$ for each group). ${ }^{+} p<0.05,{ }^{* *} p<0.01,{ }^{+++},{ }^{* * *}$, or ${ }^{\# \# \#} p<0.001$ compared with $-1 \mathrm{~d} ;{ }^{+}$saline, ${ }^{*}$ des-Arg ${ }^{10}$-HOE $140,{ }^{\#} \mathrm{HOE}$ 140. C, Percentage suppression of mechanical hyperalgesia (decrease of the withdrawal threshold), see Materials and Methods for calculation; $100 \%$ suppression corresponds to no mechanical hyperalgesia. HOE 140, open column; des-Arg ${ }^{10}$-HOE 140 , gray column. Not Ex., des-Arg HOE 140 not examined. $B_{2}$ antagonist injected before LC almost completely suppressed mechanical hyperalgesia, but neither $B_{1}$ nor $B_{2}$ antagonist $\left(0.1 \mathrm{mg} / \mathrm{kg}\right.$, s.c.) administered $2 \mathrm{~d}$ after $\mathrm{L} C$ reversed the mechanical hyperalgesia. $B_{2}$ antagonist $\left(0.1 \mathrm{mg} / \mathrm{kg}\right.$, s.c.) administered $30 \mathrm{~min}$ after $\mathrm{LC}$ had no suppressive effect, either. ${ }^{* *} p<0.01,{ }^{* * *} p<0.001$, compared with the saline group.

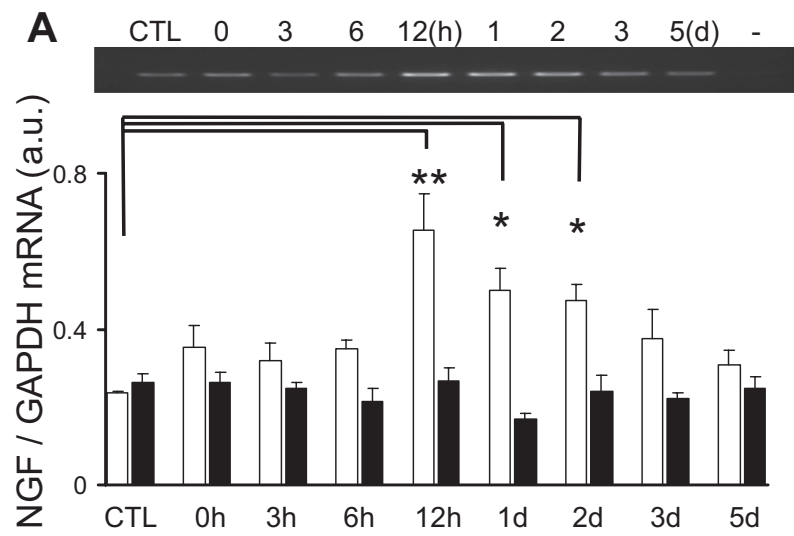

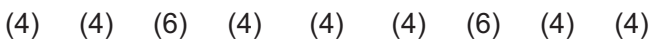

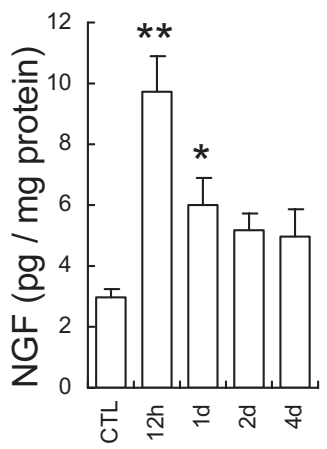

(6) (4) (4) (6) (6)

Figure 2. Upregulation of NGF in the muscle after LC. $A$, NGF mRNA level in exercised EDL muscle (open column) increased from $12 \mathrm{~h}$ to $2 \mathrm{~d}$ after $L C$, whereas no change was seen in the contralateral side (solid column). Representative reverse transcription- $P C R$ profile of NGF mRNA is at the top. $n$, Number of samples examined. $B$, NGF protein measured by ELISA increased $12 \mathrm{~h}$ to $1 \mathrm{~d}$ after $\mathrm{LC}$. ${ }^{*} p<0.05,{ }^{* *} p<0.01$ compared with the control (CTL). tide) (Blais et al., 1999; Boix et al., 2002); ATP (Li et al., 2003); and other substances (Tegeder et al., 2002). Among these substances, bradykinin, glutamate, and ATP are able to induce not only excitation/sensitization of nociceptors, but also changes in expression of neuropeptides and channels in several types of cell (Ferreira et al., 1993; Baker, 2005; Inoue et al., 2006). However, nobody paid attention to the roles of these substances in DOMS, and not many pharmacological manipulations have been performed except usage of nonsteroidal anti-inflammatory drugs (Cheung et al., 2003).

Nerve growth factor (NGF) is involved in pathological pain conditions (Lewin and Mendell, 1993; Woolf et al., 1994). NGF is produced in inflamed tissues and skeletal muscle after ischemia (Turrini et al., 2002) and nerve injury (Amano et al., 1991), and sensitizes nociceptors, resulting in hyperalgesia (Lewin et al., 1993). It was also reported that intramuscular injection of NGF induced lasting tenderness (Svensson et al., 2003).

In the present experiment, we examined involvement of bradykinin and NGF in DOMS using a rat model of DOMS in which we previously showed the existence of mechanical hyperalgesia (Taguchi et al., 2005a) and increased mechanical sensitivity of muscle thin-fiber afferents (Taguchi et al., 2005b). We found that bradykinin triggers development of muscular mechanical hyperalgesia and NGF serves in its maintenance by sensitizing muscle C-fiber receptors to mechanical stimulation.

\section{Materials and Methods}

\section{Experimental animals}

Male Sprague Dawley rats (SLC), weighing 250 $\mathrm{g}$ (7 weeks) at the beginning of the experiments, were used in this study. The animals were kept two to three per cage under a $12 \mathrm{~h}$ light/dark cycle (light between 7:00 A.M. and 7:00 P.M.) in an air-conditioned room $\left(22-24^{\circ} \mathrm{C}\right)$. They had food and water ad libitum throughout the experiment. All experiments were conducted according to the Regulations for Animal Experiments in Nagoya University, and the Fundamental Guidelines for Proper Conduct of Animal Experiments and Related Activities in Academic Research Institutions in Japan.

Protocol for LC, SC, and stretching of the extensor digitorum longus muscle $L C$ and SC. LC was applied as reported previously (Taguchi et al., 2005a). Briefly, on day 0 the animals were anesthetized with sodium pentobarbital (50 mg/kg, i.p.). LC was induced in the lower hindleg extensors [mainly the extensor digitorum longus (EDL) muscle] by electrical stimulation of the common peroneal 
nerve through a pair of needle electrodes inserted near the nerve. Electrical stimulation with the following parameters was applied for $1 \mathrm{~s}$ : current strength of three times the twitch threshold $(<100 \mu \mathrm{A})$ and a frequency of $50 \mathrm{~Hz}$ with pulse duration of $1 \mathrm{~ms}$. The ankle joint was plantar flexed in synchrony with muscle contraction with use of a linearized servomotor (CPL28T08B-06C2T, Oriental Motor) to stretch the lower hindleg extensors and then returned to the starting position over a $3 \mathrm{~s}$ resting period. This cycle was repeated for a total of 500 repetitions. The method of SCs was similar to that for LCs except for the absence of muscle stretching. After the rats recovered from anesthesia after exercise, they behaved, ate, and drank normally.

Stretching the muscle. To ensure intensive stretching similar to that during LC, direct stretching of the EDL muscle was performed as follows. A small incision $(\sim 0.5 \mathrm{~cm})$ was made on the dorsum of the right hindpaw, and the tendons of the EDL muscle were separated from the surrounding connective tissue and tightly ligated. They were manually pulled by $\sim 2$ $\mathrm{mm}$ for $1 \mathrm{~s}$ while the knee was fixed by two acrylic bars from the both sides and then returned to the starting position over $3 \mathrm{~s}$. This cycle was repeated 500 times, the same as in LC. The tendons of the contralateral EDL muscle were also ligated without stretching and served as a control.

\section{Withdrawal threshold measurement}

A Randall-Selitto analgesiometer (Ugo Basile) equipped with a probe of tip diameter $2.6 \mathrm{~mm}$ was used to measure the withdrawal threshold of the extensors of lower hindleg (EDL muscle included). A probe of tip diameter $5 \mathrm{~mm}$ was used to measure the withdrawal threshold of the gastrocnemius muscle. Use of a probe with a tip diameter of $\geq 2.6 \mathrm{~mm}$ allows measurement of muscle mechanical nociceptive threshold (Takahashi et al., 2005; Nasu et al., 2010). The animals were restrained around the trunk with a towel to calm them and treated gently during the experiments. The probe was applied to the belly of the lower hindleg extensors or lateral belly of the gastrocnemius muscle through shaved skin. The speed of force applied was set at $157 \mathrm{mN} / \mathrm{s}$, and there was a cutoff of 2450 $\mathrm{mN}$ for loading to avoid damaging the tissue. The intensity of pressure causing an escape reaction was defined as the withdrawal threshold. Each series of experiments was performed at almost the same period of time during the day to avoid circadian fluctuations. Training sessions were performed for at least four consecutive days. Measurements were performed 7 or 10 times at several-minute intervals, and the mean value of the latter five trials was taken as the threshold.

Experimenters were blind to which rats received which treatment (LC, SC, or stretching), drug, or vehicle.

\section{Drugs, calculation of percentage suppression of hyperalgesia by} drugs, and time schedule

Bradykinin antagonists. HOE 140 ( $\mathrm{B}_{2}$ antagonist, $0.01,0.1 \mathrm{mg} / \mathrm{kg}$, Sigma) and des-Arg ${ }^{10}$-HOE 140 ( $B_{1}$ antagonist, $0.1 \mathrm{mg} / \mathrm{kg}$, Sigma) were dissolved in saline and subcutaneously injected into the skin of the back 30 min before exercise or 30 min before measuring the mechanical withdrawal threshold on the second day after exercise. HOE 140 was also injected in another group of animals $30 \mathrm{~min}$ after exercise. These antagonists are receptor specific (Hock et al., 1991; Wirth et al., 1991), and the dosages used are sufficient to antagonize bradykinin in a postoperative pain model (Muratani et al., 2005) and inflamed conditions (Fox et al., 2003).

The percentage suppression of the decrease in muscle mechanical withdrawal threshold was calculated as follows. Differences in withdrawal threshold $2 \mathrm{~d}$ after exercise from that on day -1 in the vehicle group ( $\Delta$ threshold-veh) or drug group ( $\Delta$ threshold-drug) were calcu- lated, and differences (suppression) between $\Delta$ threshold-drug and $\Delta$ threshold-veh were normalized with $\Delta$ threshold-veh, and expressed as percentages.

Anti-NGF antibody. Anti-NGF antibody (10 or $30 \mu \mathrm{g}, \mathrm{R} \& \mathrm{D}$ Systems) was injected into the belly of the EDL muscle of the right hindlimb. Exact placement of the tip of the injection needle was assured by dorsiflexion of the middle three toes of the hindpaw in response to electrical stimulation through the electrode attached to the injection needle.

A volume of $5 \mu \mathrm{l}$ (for a $10 \mu \mathrm{g}$ injection) to $7 \mu \mathrm{l}$ (for a $30 \mu \mathrm{g}$ injection) of anti-NGF antibody was injected under halothane anesthesia $(2 \%$, Takeda Chemical Industries). An equivalent volume ( $5 \mu \mathrm{l}$ for saline, and 5 and $7 \mu \mathrm{l}$, respectively, for 10 and $30 \mu \mathrm{g}$ of normal goat IgG in PBS) was injected into the right EDL muscle in the control group. They were injected $6 \mathrm{~h}$ after exercise or on the second day after exercise. Withdrawal threshold on the second day after LC was measured twice, once before antibody injection and once 3-4 h afterward. We also checked the effects of anti-NGF antibody on withdrawal thresholds in normal rats (30 $\mu \mathrm{g}$ in $7 \mu \mathrm{l}$, i.m.) and the systemic effects of this antibody injected intraperitoneally $(30 \mu \mathrm{g}$ in $7 \mu \mathrm{l}) 2 \mathrm{~d}$ after LC.

Anti-IL-6 antibody. Anti-IL-6 antibody ( $1 \mu \mathrm{g} / 5 \mu \mathrm{l}$ PBS, R \& D Systems) was injected into the belly of the EDL muscle $2 \mathrm{~d}$ after LC, similarly to the anti-NGF antibody. The dosage used was reported to be effective in a burn-injury model (Summer et al., 2008).

NGF. NGF [NGF- $\beta$ (rat recombinant), Sigma, 0.2 or $0.8 \mu \mathrm{M}, 20 \mu \mathrm{l}$ ] was injected into the lateral belly of the gastrocnemius muscle of the right hindlimb under isoflurane anesthesia (2\%, Abbott). An equivalent volume of vehicle solution (PBS) was injected into the right gastrocnemius muscle of the control group. Withdrawal threshold was measured before injection, and $0.5,1,2,3,4$, and $5 \mathrm{~h}$ and $1,2,3,4$, and $5 \mathrm{~d}$ after injection.

Bradykinin. Bradykinin (Peptide Institute, 10 or $30 \mu \mathrm{g}$ in $5 \mu \mathrm{l}$ ) was injected into the right EDL muscle over 30 min using a microsyringe pump under halothane anesthesia. An equivalent volume of vehicle solution (PBS) was injected into the right EDL muscle of the control group. Withdrawal threshold was measured before injection, 2 and $6 \mathrm{~h}$ after injection, and 1, 2, 3, 4, and $5 \mathrm{~d}$ after injection. The amount of bradykinin was set at $>10,000$ times the amount reported to be released into superfusate in an in vitro experiment (Boix et al., 2002), on the assumption that only a small part of the produced bradykinin was released into the superfusate and recovered from it, and that it would be rapidly metabolized in vivo. 


\section{$R N A$ isolation and reverse transcription-PCR}

The EDL muscle was removed under anesthesia immediately after LC ( 0 h); 3, 6, and $12 \mathrm{~h}$ after LC; and 1, 2, 3, and $5 \mathrm{~d}$ after LC. To examine whether there was any interaction between bradykinin and NGF, additional samples were taken after the treatment with HOE $140(0.1 \mathrm{mg} / \mathrm{kg}$, s.c.). This drug was administered before LC, and the EDL muscle was removed $12 \mathrm{~h}$ after LC. Tissue samples from individual rats were weighed, $30 \mathrm{mg}$ of each sample was homogenized in lysis buffer, and total RNA was extracted with RNeasy Fibrous Tissue Mini Kit (QIAGEN). The amount of total RNA was evaluated by spectrophotometry (Genequantpro, GE Healthcare). One microgram samples of RNA preparations were transcribed to cDNA with M-MLV Reverse Transcriptase (Promega) at $42^{\circ} \mathrm{C}$ for $50 \mathrm{~min}$. Five microliter aliquots of the resultant solution of reverse transcriptase reaction were taken into each PCR and amplified with NGF primers (sense: $5^{\prime}$-ttcggacactctggatttagact- $3^{\prime}$; antisense: $5^{\prime}$ gatttggggctcggcacttg- $3^{\prime}$ ) or primers for interleukin (IL)-1 $\beta$ (sense: $5^{\prime}$ aagccaacaagtggtattctc- $3^{\prime}$; antisense: $5^{\prime}$-ttgtttgggatccacactctc- $3^{\prime}$ ), IL-6 (sense: $5^{\prime}$-atgttgttgacagccactgc- $3^{\prime}$; antisense: $5^{\prime}$-acagtgcatcatcgctgttc- $3^{\prime}$ ) or tumor necrosis factor (TNF)- $\alpha$ (sense: $5^{\prime}$-atgtggaactggcagaggag- $3^{\prime}$; antisense: $5^{\prime}$ ggccatggaactgatgagag- $\left.3^{\prime}\right)$. The data were measured at the exponential phases of the PCRs. Specifically, the reactions were run for 33 cycles $\left(94^{\circ} \mathrm{C}, 30 \mathrm{~s}\right.$; $\left.55^{\circ} \mathrm{C}, 30 \mathrm{~s} ; 72^{\circ} \mathrm{C}, 1 \mathrm{~min}\right)$ for NGF; 35 cycles $\left(94^{\circ} \mathrm{C}, 30 \mathrm{~s} ; 53^{\circ} \mathrm{C}, 30 \mathrm{~s} ; 72^{\circ} \mathrm{C}, 1\right.$ min) for IL- $1 \beta ; 35$ cycles $\left(94^{\circ} \mathrm{C}, 30 \mathrm{~s} ; 55^{\circ} \mathrm{C}, 30 \mathrm{~s} ; 72^{\circ} \mathrm{C}, 1 \mathrm{~min}\right)$ for IL-6; and 35 cycles $\left(94^{\circ} \mathrm{C}, 30 \mathrm{~s} ; 66^{\circ} \mathrm{C}, 30 \mathrm{~s} ; 72^{\circ} \mathrm{C}, 1 \mathrm{~min}\right)$ for TNF- $\alpha$. Glyceraldehyde-3phosphate dehydrogenase (GAPDH), as an internal standard, was also amplified using the following primers: sense: $5^{\prime}$-gtgaaggtcggtgtcaacggattt- $3^{\prime}$; and antisense: $5^{\prime}$-cacagtcttctgagtggcagtgat- $3^{\prime}$. The PCR was run for 21 cycles with an annealing temperature of $55^{\circ} \mathrm{C}$. PCR products were resolved by electrophoresis through a $1.5 \%$ agarose gel. The amplified DNA fragments were detected by ethidium bromide staining. The ethidium bromide-stained bands were visualized by UV light, and the optical density of the bands was analyzed with ImageJ software (free software developed by National Institutes of Health). The values were normalized against GAPDH for analysis.

\section{NGF ELISA}

NGF levels in muscle tissue extracts were measured by ELISA (NGF $E_{\max }$ ImmunoAssay System, Promega) according to the manufacturer's instructions. The minimum assay sensitivity for NGF was $15.6 \mathrm{pg} / \mathrm{ml}$. All measurements were performed in duplicate.

\section{Single-fiber recording from muscle C-afferent fibers}

Rat EDL muscle-common peroneal nerve preparation was used. The methods of obtaining single-fiber activities, stimulation, and analysis were described previously (Taguchi et al., 2005b). Briefly, the EDL muscle from both hindlimbs was carefully removed with the common peroneal nerve attached under pentobarbital anesthesia $(50 \mathrm{mg} / \mathrm{kg}$, i.p.). Animals were killed with an overdose of the same anesthetic after removal of the preparation. The isolated preparation was then placed in an organ bath with the proximal and distal ends of the EDL muscle pinned in the test chamber. The preparation was maintained at $34.0 \pm 0.5^{\circ} \mathrm{C}, \mathrm{pH}$ 7.4, under superfusion with modified Krebs-Henseleit solution (Krebs solution), which contained (in $\mathrm{mm}$ ) $110.9 \mathrm{NaCl}, 4.7 \mathrm{KCl}, 2.5 \mathrm{CaCl}_{2}, 1.2$ $\mathrm{MgSO}_{4}, 1.2 \mathrm{KH}_{2} \mathrm{PO}_{4}, 25.0 \mathrm{NaHCO}_{3}$, and 20.0 glucose, and was continuously bubbled and equilibrated with a gas mixture of $95 \% \mathrm{O}_{2}$ and $5 \%$ $\mathrm{CO}_{2}$. The common peroneal nerve was drawn through a hole to the recording chamber filled with paraffin oil. Single-fiber activities were obtained by the dissection method. The muscle C-fiber sensory receptors used in this experiment fulfilled the following criteria: (1) sensitivity to mechanical stimulation by probing with a glass rod; (2) no intensitydependent increase in the discharge rate while the muscle was stretched by a length of a few millimeters (to exclude muscle spindle afferents); and (3) conduction velocity slower than $2.0 \mathrm{~m} / \mathrm{s}$. The conduction velocity of the fibers was calculated from the distance and conduction latency of a spike induced by electrical stimulation of the receptive field (intensity just above the threshold to obtain constant action potentials, up to $50 \mathrm{~V}$ with pulse duration of $100-500 \mu \mathrm{s}$ ). Mechanical stimulus was applied by a stimulator with feedback regulation of the force (manufactured by S. Aizawa, Goto College of Medical Arts and Science, Tokyo, Japan). The stimulator had a plastic, cylindrical probe with a flat tip (tip size, 2.28

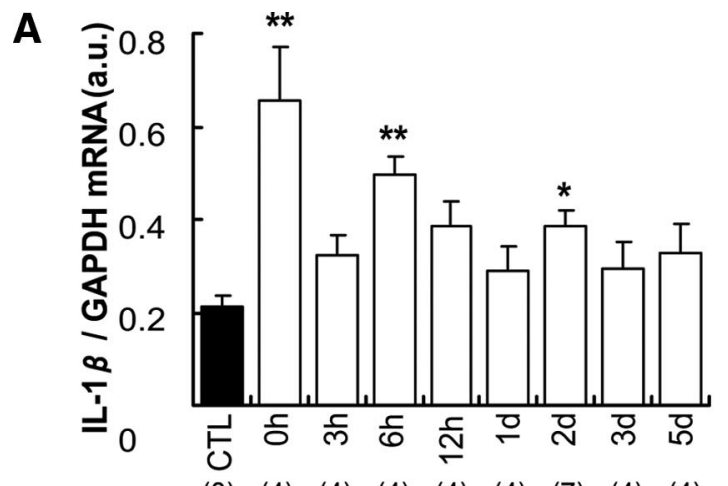

(8) (4) (4) (4) (4) (4) (7) (4) (4)

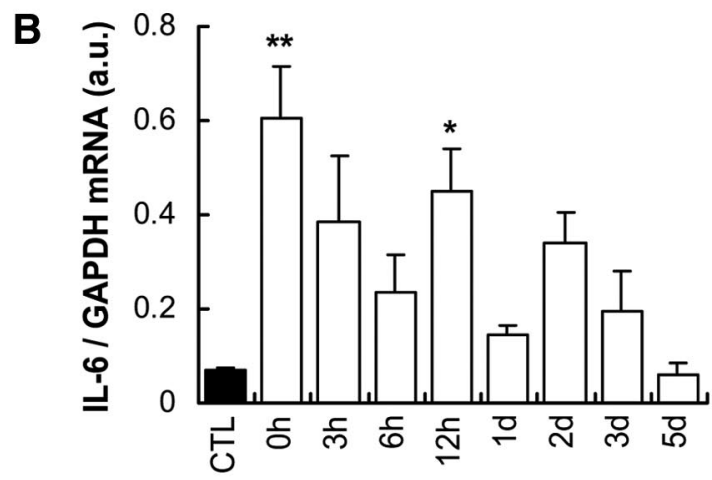

(4) (4) (6) (4) (4) (4) (6) (4) (4)

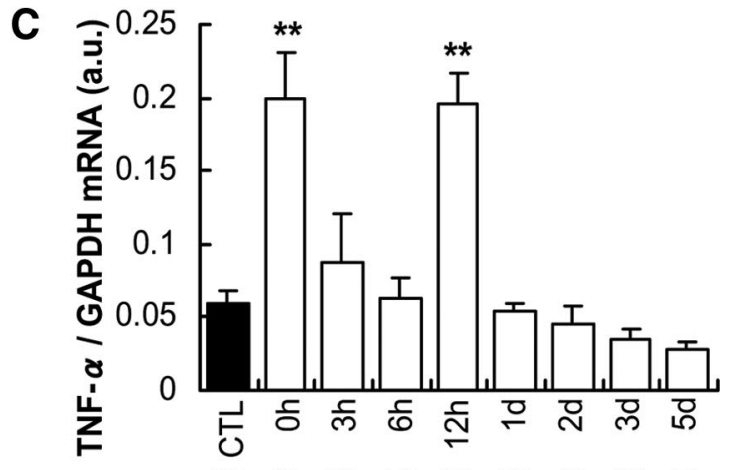

(4) (4) (4) (4) (4) (3) (4) (4) (4)

Figure 4. Time course of changed expression of IL-1 $\beta, \mathrm{IL}-6$, and TNF- $\alpha$ mRNAs in exercised EDL muscle after LC. $\boldsymbol{A}-\boldsymbol{C}$, Expression of IL-1 $\beta(\boldsymbol{A})$, IL-6 (B) , and TNF- $\alpha(\boldsymbol{C})$ mRNAs increased biphasically or triphasically after LC. Notably, a marked increase of these mRNAs was observed immediately after $L C . n$, number of samples examined. ${ }^{*} p<0.05,{ }^{* *} p<0.01$ compared with the control group (CTL), Dunnett's multiple-comparison test after one-way ANOVA.

$\mathrm{mm}^{2}$ ). A ramp mechanical stimulus, linearly increasing from 0 to 196 $\mathrm{mN}$ in $10 \mathrm{~s}$, was applied to the most sensitive point of the identified receptive field. The mechanical threshold was defined as the intensity that induced a discharge that exceeded the mean frequency plus 2 SDs of spontaneous discharges during the control period, when there were two or more consecutive discharges exceeding this level. Mechanical response was examined two times with an interval of $10 \mathrm{~min}$, and then NGF [NGF- $\beta$ (rat recombinant), Sigma, $0.8 \mu \mathrm{M}, 5 \mu \mathrm{l} / 5 \mathrm{~s}$ ] was injected $2 \mathrm{~mm}$ from the receptive field of a fiber through a 30 ga needle. Thereafter, mechanical response was examined 10, 20, 30, 60, and 120 min after the injection of NGF. The threshold and discharge numbers of the PBS group at each time point were averaged. Each value for both the NGF and PBS groups at each time point was normalized with this averaged value, and expressed as a percentage. The mean and SEM were then calculated.

\section{Statistical analysis}

Change in withdrawal threshold during the observation period was examined with one-way ANOVA followed by Bonferroni's multiple- 
comparison test, compared with the threshold on day - 1 . Percentage suppression was statistically analyzed with one-way ANOVA followed by Bonferroni's multiple-comparison test, compared with the control (vehicle) group. The effects of bradykinin (two dosages) or PBS intramuscular injection were analyzed with two-way ANOVA.

The change in mRNA and protein was examined with one-way ANOVA followed by Dunnett's multiple-comparison test, compared with day -1 . The change in mRNAs after SC and stretch was examined with one-way ANOVA followed by Dunnett's multiplecomparison test, compared with the control group. The effect of HOE 140 on mRNA and protein expression of NGF at $12 \mathrm{~h}$ was examined with an unpaired $t$ test.

In single-fiber recording experiments, the response threshold and number of discharges were statistically analyzed with the MannWhitney $U$ test for absolute values at each time point. $p<0.05$ was considered statistically significant.

\section{Results}

\section{Effects of bradykinin receptor antagonists on DOMS}

To determine whether DOMS is mediated by bradykinin receptors, we examined the effects of $\mathrm{B}_{1}$ and $\mathrm{B}_{2}$ bradykinin antagonists on muscle mechanical hyperalgesia after LC. In the saline-injected group, the mechanical withdrawal threshold of exercised muscle measured by Randall-Selitto analgesiometer decreased $1 \mathrm{~d}$ after LC, and this decrease in threshold reached the lowest level $2 \mathrm{~d}$ after exercise (Fig. 1A), which means muscular mechanical hyperalgesia developed, as reported previously (Taguchi et al., 2005a). When a $\mathrm{B}_{2}$ bradykinin receptor antagonist, $\mathrm{HOE} 140$ ( 0.01 or $0.1 \mathrm{mg} / \mathrm{kg}$, s.c.), was administered 30 min before LC, mechanical hyperalgesia did not appear at any time during the observation period up to $5 \mathrm{~d}$ after LC (Fig. $1 A$ ). Since the effect of HOE 140 lasts only for several hours in vivo (Bao et al., 1991), it is worth noting that generation of mechanical hyperalgesia was completely suppressed with a single injection. To determine the exact time of the action of bradykinin, we injected HOE 14030 min after LC and found it had no effect at all (Fig. 1C). Meanwhile, HOE 140 injected $2 \mathrm{~d}$ after LC failed to reverse mechanical hyperalgesia (Fig. $1 B, C$ ). Unlike the $\mathrm{B}_{2}$ receptor antagonist, a $\mathrm{B}_{1}$ receptor antagonist, des- $\operatorname{Arg}{ }^{10}-\operatorname{HOE} 140(0.1 \mathrm{mg} / \mathrm{kg}$, s.c.) failed to suppress the mechanical hyperalgesia after LC regardless of the timing of the injection (Fig. $1 A, C$ ).

\section{The time course of NGF upregulation in LC loaded muscle}

Next, we examined the possible involvement of NGF. NGF mRNA in exercised EDL muscle significantly increased $12 \mathrm{~h}$ after LC and remained at increased levels up to $2 \mathrm{~d}$ after LC (Fig. $2 \mathrm{~A}$ ). This time course of increased NGF mRNA was comparable with the time course of muscle mechanical hyperalgesia after LC. Clear upregulation of NGF protein in exercised EDL muscle was observed

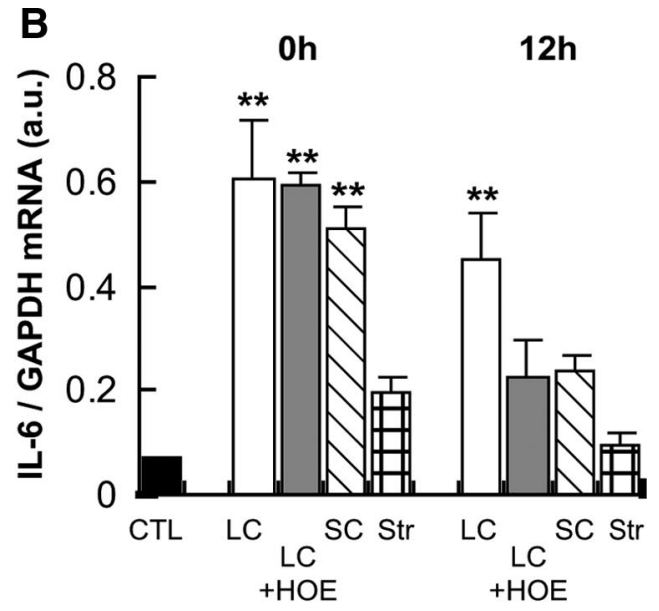

$12 \mathrm{~h}$
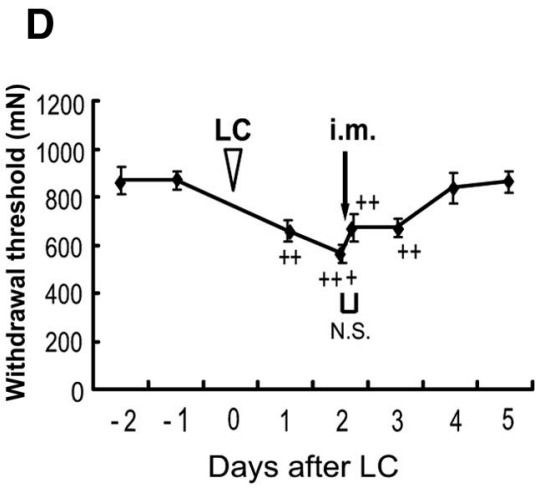

Figure 5. $\quad \boldsymbol{A}-\boldsymbol{D}$, Effects of HOE 140 on IL-1 $\beta(\boldsymbol{A})$, IL-6 (B), and TNF- $\alpha(\boldsymbol{C})$ mRNAs after LC, their changed expression after SC and - 6 and TNF- $\alpha$ mRNA immediately after LC. Increase of IL- 6 mRNA $12 \mathrm{~h}$ after LC was suppressed by HOE 140 but not TNF- $\alpha$ mRNA. 8) and 0 s smples in stretching, the time of intramuscular injection of anti-IL- 6 antibody. ${ }^{++} p<0.01,{ }^{+++} p<0.001$ compared with $-1 \mathrm{~d}$ in D. N.S., no significant difference before and after injection, Bonferroni's multiple-comparison test after one-way ANOVA. Intramuscular injection of anti-IL-6 antibody $2 \mathrm{~d}$ after LC (D) did not affect muscle mechanical hyperalgesia $(n=6)$.

by ELISA $12 \mathrm{~h}$ to $1 \mathrm{~d}$ after LC (Fig. $2 \mathrm{~B}$ ), and NGF protein level tended to remain higher than in the control up to $4 \mathrm{~d}$ after LC.

DOMS can be easily induced by lengthening contraction but not by either shortening contraction or stretching. We confirmed that neither shortening contraction (Fig. $3 A$ ) nor stretching (data not shown) led to mechanical hyperalgesia. Neither shortening contraction nor stretching induced a statistically significant upregulation of NGF mRNA $12 \mathrm{~h}$ after exercise (Fig. 3 B).

We also examined the change in mRNAs of other cytokines (IL-1 $\beta$, IL-6, and TNF- $\alpha$ ). Biphasic or triphasic increases were observed at 0,6 , or $12 \mathrm{~h}$ and $2 \mathrm{~d}$ (in the case of IL-1 $\beta$ ) after LC (Fig. $4 A-C$ ). Shortening contraction that did not induce mechanical hyperalgesia (Fig. $3 A$ ) also induced an increase in mRNA of all three cytokines immediately after exercise (Fig. $5 A-C$ ). In addition, HOE 140 failed to suppress the upregulation of TNF- $\alpha$ (Fig. 5C). Upregulation of IL-6 $12 \mathrm{~h}$ after LC was suppressed by HOE 140, but anti-IL- 6 antibody $(1 \mu \mathrm{g}$ in $5 \mu \mathrm{l})$ injected into the EDL muscle $2 \mathrm{~d}$ after LC failed to reverse the hyperalgesia (Fig. $5 D$ ). These data suggest that these substances are unlikely to contribute significantly to mechanical hyperalgesia after exercise. However, the possibility remains that these substances play some 


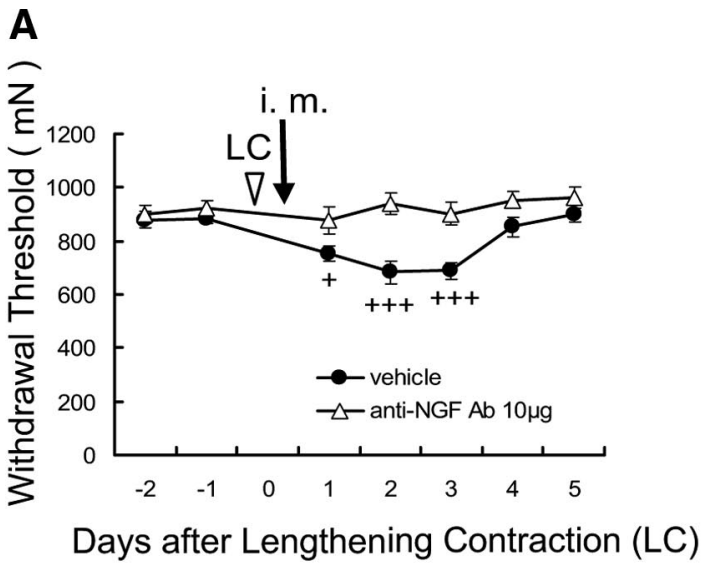

B

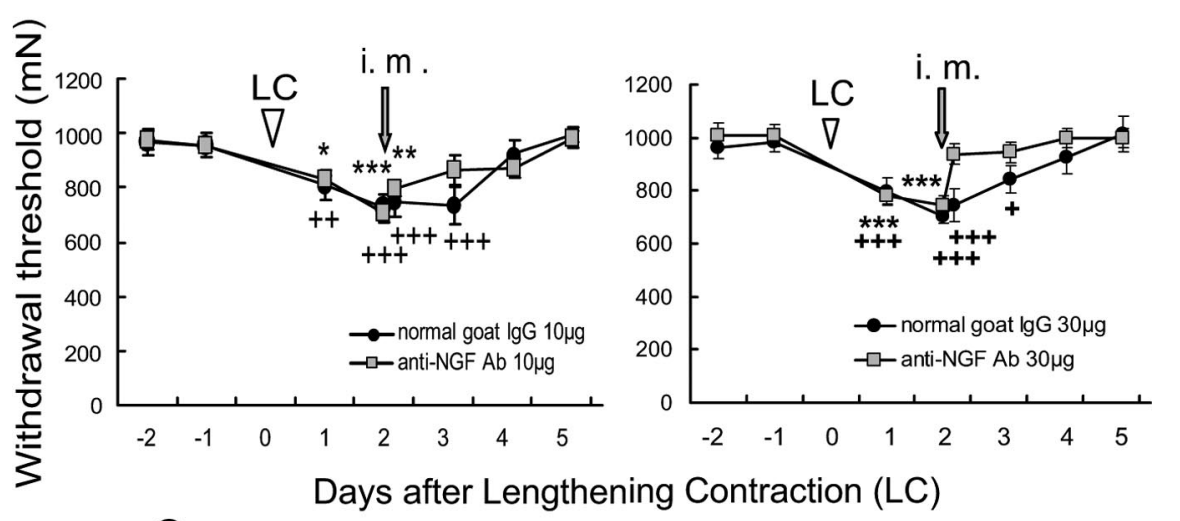

C

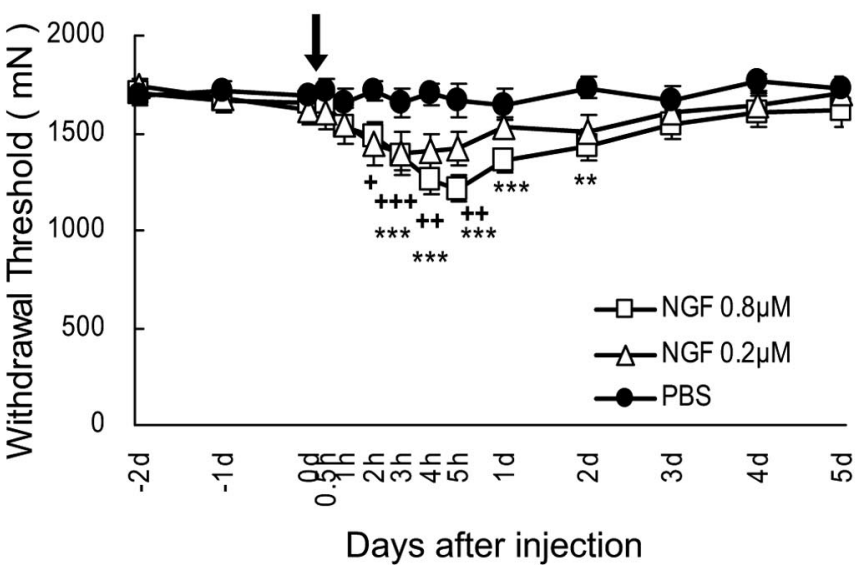

Figure 6. Effects of intramuscular injection of anti-NGF antibody and NGF. $A, B$, Anti-NGF antibody (10 $\mu$ g, i.m.) $6 \mathrm{~h}(\boldsymbol{A})$ and (30 $\mu \mathrm{g}$, i.m.) $2 \mathrm{~d}$ ( $\boldsymbol{B}$, right) after $\mathrm{LC}$ blocked and reversed, respectively, the mechanical hyperalgesia seen after $\mathrm{LC}(n=6$ in $\boldsymbol{A} ; n=8$ in $\boldsymbol{B}$, right) in the saline $(\boldsymbol{A})$ and normal goat $\lg (\boldsymbol{B})$ control groups (solid circle). However, anti-NGF antibody (10 $\mu \mathrm{g}$, i.m.) injected $2 \mathrm{~d}$ after $\mathrm{LC}$ failed to reverse the generated hyperalgesia after $\mathrm{LC}\left(\boldsymbol{B}\right.$, left, $n=6$ for each group). ${ }^{+}{ }_{\text {or }}{ }^{*} p<0.05,{ }^{++}{ }^{+}$or ${ }^{* *} p<$ $0.01,{ }^{+++}$or ${ }^{* * *} p<0.001$ compared with $-1 \mathrm{~d}$; ${ }^{+}$control group, ${ }^{*}$ anti-NGF antibody. C, NGF $(20 \mu l)$ injected into the gastrocnemius muscle decreased the muscular mechanical nociceptive threshold ( $n=8$ for each group). ${ }^{+} p<0.05,{ }^{++}$or ${ }^{* *} p<0.01,{ }^{+++}$or ${ }^{* * *} p<0.001$ compared with $-1 \mathrm{~d} ;{ }^{+} 0.2 \mu \mathrm{m}$ group,${ }^{*} 0.8 \mu \mathrm{m}$ group. Note that the baseline withdrawal threshold was higher than in $\boldsymbol{A}$ and $\boldsymbol{B}$ because a larger probe was used to measure the threshold and that the horizontal axis is not linear.

role in the intermediary processes to produce mechanical hyperalgesia.

\section{Involvement of NGF in muscle mechanical hyperalgesia} after LC

To confirm the involvement of NGF in muscular mechanical hyperalgesia after LC, we injected anti-NGF antibodies intramus- cularly. Anti-NGF antibody (10 $\mu \mathrm{g}$ in 5 $\mu \mathrm{l})$ injected into the EDL muscle $6 \mathrm{~h}$ after LC completely blocked generation of mechanical hyperalgesia (Fig. 6A). The same dose of anti-NGF antibody injected $2 \mathrm{~d}$ after LC failed to reverse the generated hyperalgesia (Fig. 6B, left), but a triple dose (30 $\mu \mathrm{g}$ in $7 \mu \mathrm{l})$ clearly $(\sim 70 \%)$ but partially reversed existing mechanical hyperalgesia in 3-4 h (Fig. 6 B, right). Anti-NGF antibody $(30 \mu$ g, i.m.) did not affect the mechanical withdrawal thresholds in normal rats $(p>0.05$, one-way ANOVA, $n=$ $5)$. This indicates that the muscular withdrawal threshold is not influenced by NGF under normal conditions. We also found that the antibody administered intraperitoneally $2 \mathrm{~d}$ after LC did not attenuate muscle mechanical hyperalgesia ( $p>0.05$, no significant difference in the withdrawal threshold before and after injection, Bonferroni's test after one-way ANOVA, $n=6$ ), suggesting that NGF works locally in the muscle.

To confirm whether NGF induced long-lasting muscular mechanical hyperalgesia, we injected NGF into the gastrocnemius muscle and measured withdrawal threshold over several days. NGF $(0.2 \mu \mathrm{M}$, $20 \mu \mathrm{l})$ induced mechanical hyperalgesia 2-5 h after injection (Fig. 6C). Longerlasting mechanical hyperalgesia, up to $2 \mathrm{~d}$, was induced by NGF injection at the fourfold higher concentration of $0.8 \mu \mathrm{M}$ (Fig. 6C).

\section{Relationships between bradykinin and NGF}

To clarify whether bradykinin released during exercise induces NGF upregulation in exercised muscle, we measured NGF mRNAs or proteins in the muscle after the $\mathrm{B}_{2}$ receptor antagonist injection. HOE 140 at the same dosage $(0.1 \mathrm{mg} / \mathrm{kg}$, s.c.) as that which suppressed generation of DOMS significantly suppressed the increase of NGF mRNA $12 \mathrm{~h}$ after exercise, from $0.65 \pm 0.09$ arbitrary units (no drug group, normalized with GAPDH mRNA) to $0.38 \pm 0.03$ arbitrary units (HOE 140injected group, $n=4$ each, $p<0.05$, unpaired $t$ test). The increase in NGF protein $12 \mathrm{~h}$ after LC was also significantly suppressed (no drug group, $9.70 \pm 1.21 \mathrm{pg} / \mathrm{mg}$ protein; HOE 140-injected group, $5.38 \pm$ $0.49 \mathrm{pg} / \mathrm{mg}$ protein, $p<0.05, n=4$ each).

Contrary to our expectation, injection of bradykinin alone (10 and $30 \mu \mathrm{g}$ over $30 \mathrm{~min}$ ) into EDL muscle failed to induce persistent muscle mechanical hyperalgesia (Fig. 7A) and caused a small decrease in withdrawal threshold for only a short time (until $\sim 6$ $\mathrm{h}$ after injection). The control PBS group also showed a small decrease in mechanical threshold. There was no significant interaction between time and treatment $\left(F_{(16,112)}=1.09, p>0.05\right)$, 


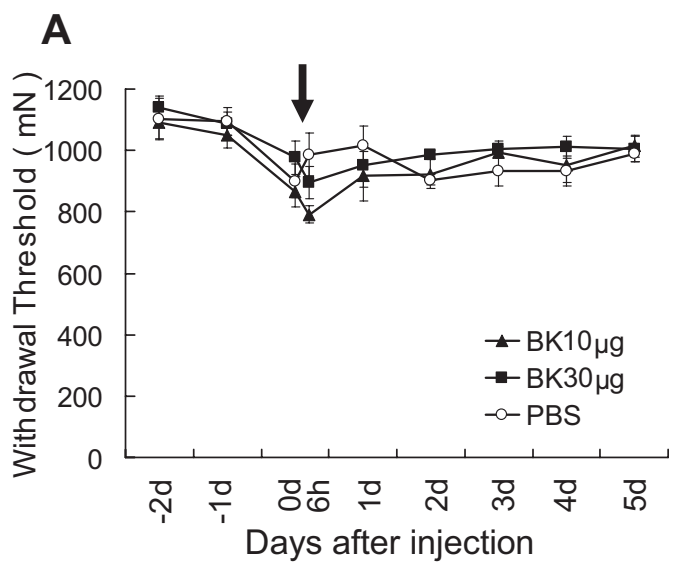

B
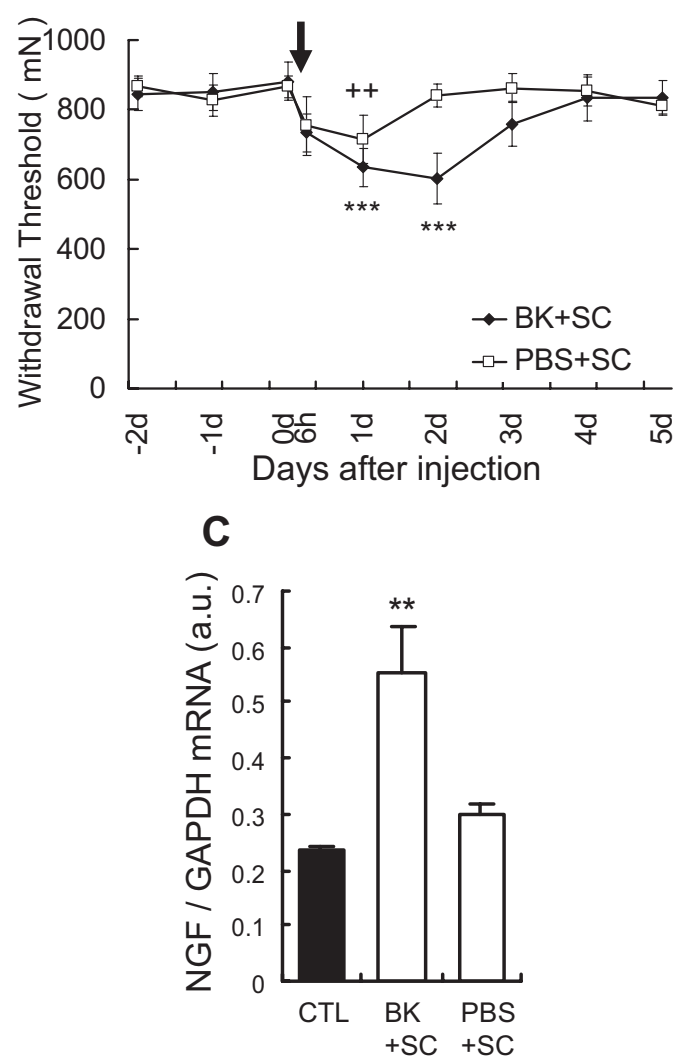

Figure 7. Effects of intramuscular injection of bradykinin (BK), and the combination of bradykinin and shortening contraction. $A, B K$ or PBS injected into the EDL muscle tended to decrease the muscular mechanical nociceptive threshold for a short time ( $n=6$ for bradykinin group, $n=5$ for PBS group), but there was no significant interaction between time and treatment $\left(F_{(16,112)}=1.09, p>0.05\right)$, and no significant effect in treatment $\left(F_{(2,112)}=0.93, p>\right.$ 0.05 , two-way ANOVA with repeated measures). Arrow, Time points for injection (on day 0 ). $B$, The combination of bradykinin and $\mathrm{SC}(\mathrm{BK}+\mathrm{SC}$ ) induced muscle mechanical hyperalgesia longer than injection of bradykinin alone. ${ }^{++} p<0.01,{ }^{* * *} p<0.001$ compared with $-1 \mathrm{~d}$; ${ }^{+} \mathrm{PBS}+\mathrm{SC}$ group; ${ }^{*} \mathrm{BK}+\mathrm{SC}$ group. Arrow, Time points for injection during shortening contraction (on day 0). C, NGF mRNA level in EDL muscle increased $12 \mathrm{~h}$ after BK + SC but not PBS + SC treatment (open columns) compared with the control group (CTL) (no treatment, solid column). ${ }^{* *} p<0.01, n=6$ for each group.

nor was there a significant effect in treatment $\left(F_{(2,112)}=0.93, p>\right.$ 0.05 , two-way ANOVA with repeated measures). Next, we examined whether additional shortening contraction caused mechanical hyperalgesia. We found that the combination of bradykinin injection (10 $\mu \mathrm{g}$ over $30 \mathrm{~min}$ ) and shortening contraction (30 min) induced longer-lasting muscle mechanical hyperalgesia (Fig. $7 B$ ).
This amount of bradykinin combined with shortening contraction induced NGF mRNA upregulation $12 \mathrm{~h}$ after injection (Fig. 7C). Mechanical hyperalgesia was observed in the group that received PBS injection and shortening contraction, but lasted only up to $1 \mathrm{~d}$ after injection (Fig. $7 B$ ), and there was no significant NGF mRNA upregulation (Fig. 7C).

\section{NGF sensitized nociceptors to mechanical stimulation}

Our observations that mechanical hyperalgesia was partially reversed 3-4 h after intramuscular injection of a small amount anti-NGF antibody, and that muscular mechanical hyperalgesia occurred $2 \mathrm{~h}$ after injection of NGF, suggested that NGF peripherally sensitized nociceptors to mechanical stimulation. To investigate this possibility, we recorded single-muscle, thin-fiber activities from the EDL muscle-common peroneal nerve preparations in vitro (Taguchi et al., 2005b) and examined whether NGF sensitized the mechanical sensitivity in the periphery of these preparations in a short period.

A total of 51 muscle thin fibers divided into two groups was recorded. One group received an NGF injection $(0.8 \mu \mathrm{M}, 5 \mu \mathrm{l}$ over $5 \mathrm{~s}$ ) near the receptive field ( $n=25$, NGF group), and the other group received a PBS $(\mathrm{pH} 7.4,5 \mu \mathrm{l})$ injection $(n=26, \mathrm{PBS}$ group) as a control. Intramuscular injection of NGF elicited weak excitation in 5 of $25(20 \%)$ thin afferents, while that of PBS induced no excitation at all ( 0 of 26 fibers). The buildup of the response to NGF was relatively slow with response latencies of 1.5-24 s. The peak discharge rate ranged from 4 to $17 \mathrm{impulses} / \mathrm{s}$ with response duration of 20-180 s. Four fibers in the NGFactivated fibers were sensitive to heat $\left(\sim 34-50^{\circ} \mathrm{C}\right)$. Before injection, the response to mechanical stimulation was stable. Ten to twenty minutes after NGF injection, thin-fiber afferents showed decreased response threshold (Fig. $8 B, C$ ) and increased response magnitude (Fig. $8 B, D$, NGF group) to mechanical stimulations, when compared with afferents in the PBS group (Fig. $8 A, C, D$ ). These changes lasted as long as observation continued (up to 120 min) (Fig. $8 B-D$ ). It must be mentioned that there were no differences between the groups in regard to conduction velocities (Table 1), background discharge rates during $60 \mathrm{~s}$ control period at three time points before the injection $(-20,-10 \mathrm{~min}$, and just before injection; data not shown), incidence and threshold of the heat response (data not shown), or mechanical threshold and magnitude of the response (total number of evoked discharges during a $10 \mathrm{~s}$ stimulation period) (Table 1). This result demonstrates that NGF had a clear ability to sensitize muscular thin afferents to mechanical stimulation in the periphery, although it had only a weak excitation effect.

\section{Discussion}

We have demonstrated that bradykinin released during exercise plays an essential role, through $\mathrm{B}_{2}$ receptors, in the muscle mechanical hyperalgesia after exercise (DOMS), by showing that $\mathrm{B}_{2}$ antagonist applied shortly before exercise but not $30 \mathrm{~min}$ after exercise prevented the development of DOMS. Different from previous reports (Armstrong et al., 1983; Smith, 1991; Pyne, 1994), signs of inflammation and muscle damage were minimal (almost absent) in our DOMS model (Fujii et al., 2008), but mechanical hyperalgesia was clear. Furthermore, Crameri et al. (2007) reported that there was no correlation between increases of destroyed Z-lines or macrophages in the muscle and muscle tenderness in humans. Release of bradykinin during exercise was previously reported (Blais et al., 1999; Taguchi et al., 2000; Boix et al., 2002; Langberg et al., 2002), and this bradykinin was reported to be mostly kallidin-like peptide (arg-bradykinin) in the rat 
A

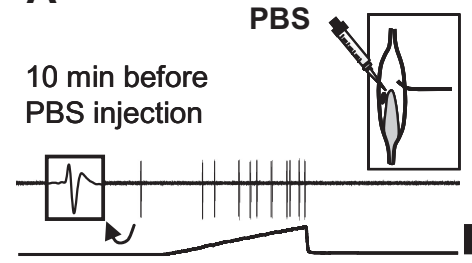

120 min after PBS injection

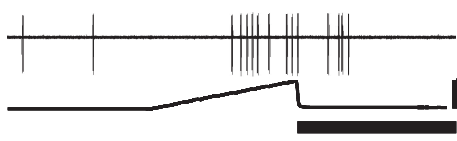

$10 \mathrm{~s}$
B

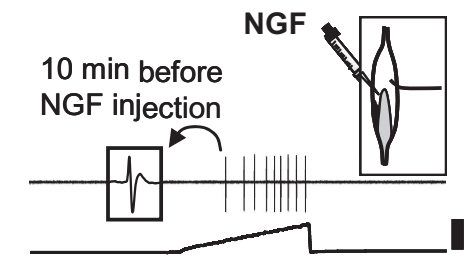

120 min after NGF injection

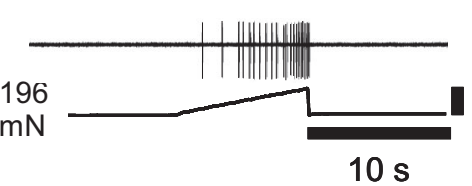

D

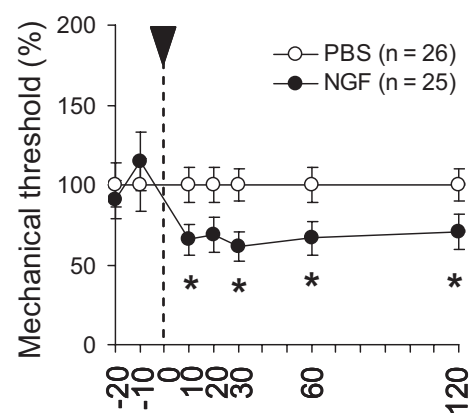

Time after injection ( $\mathrm{min}$ )

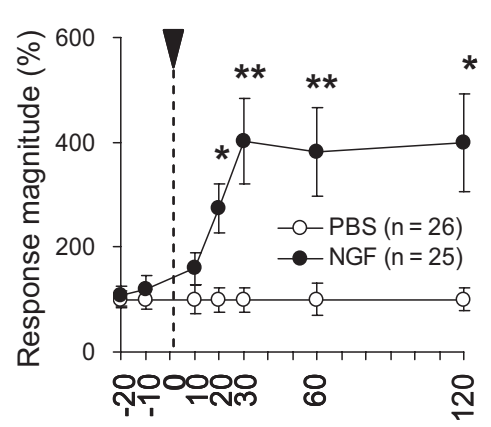

Time after injection (min)
Figure 8. NGF-induced sensitization of $\mathbf{C}$-fiber responses to mechanical stimulation. $\boldsymbol{A}, \boldsymbol{B}$, Raw recordings of single-muscle (-fiber responses (upper trace, action potentials were retouched because raw trace was too pale to see) to mechanical stimulation (lower trace) before and 120 min after injection of PBS $(\boldsymbol{A})$ or NGF $(\boldsymbol{B})$. Right inset shows the receptive field (solid circle) of the recorded fiber and NGF injection site in the EDL muscle. Shadow indicates the tendinous area, and the line at right shows the innervating nerve. Left inset shows the spike form. $C, D$, Summary of NGF effects on muscle thin-fiber afferent responses to mechanical stimulation. Intramuscularly injected NGF decreased the mechanical threshold $(\boldsymbol{C})$ and increased the number of discharges $(\boldsymbol{D})$ responding to the mechanical stimulation $(0-196 \mathrm{mN}$ in $10 \mathrm{~s})$. Values are presented as the percentage of the averaged value of PBS group at each time point (for calculation, see Materials and Methods). ${ }^{*} p<0.05,{ }^{* *} p<0.01$ compared with PBS group at each time point.

Table 1. Mechanical threshold and response magnitude of muscle C-fiber receptors in PBS and NGF groups

\begin{tabular}{lcc}
\hline & PBS group & NGF group \\
\hline Conduction velocity (m/s) & $0.58(0.45-0.75)$ & $0.65(0.52-0.79)$ \\
Mechanical threshold (-20 min) $(\mathrm{mN})$ & $5.9(3.9-8.9)$ & $5.9(4.0-9.3)$ \\
Response ( $-20 \mathrm{~min})($ spikes) & $25.8(7.4-38.0)$ & $28.0(8.2-45.1)$ \\
Mechanical threshold (-10 min) $(\mathrm{mN})$ & $4.5(3.5-10.6)$ & $6.2(3.0-17.6)$ \\
Response (-10 min) (spikes) & $19.4(6.0-36.2)$ & $25.0(6.7-40.8)$ \\
\hline
\end{tabular}

Values in the table represent median (interquartile range). There were no significant differences between the PBS and NGF groups. -20 and $-10 \mathrm{~min}, 20$ and $10 \mathrm{~min}$ before injection, respectively.

(Boix et al., 2002). However, since bradykinin, kallidin, and kallidin-like peptide bind $\mathrm{B}_{2}$ bradykinin receptors, and $\mathrm{B}_{2}$ antagonist cannot differentially block the action of these three, here we used "bradykinin" to refer to all three of these kinins. The absence of an effect from bradykinin receptor antagonists administered after development of DOMS showed that bradykinin is not the substance that maintains mechanical hyperalgesia, which means that bradykinin is not responsible for the increased mechanical sensitivity of thin-fiber receptors after LC (Taguchi et al., 2005b).

Arg-bradykinin, which is liberated from low-molecularweight kininogen in rats (Hilgenfeldt et al., 2005), may be released from vascular endothelial cells because low-molecular- weight kininogen exists only in vascular systems but not in plasma or muscle cells (Okamoto et al., 1998; Takano et al., 2000).

We found a $12 \mathrm{~h}$ delay in upregulation of NGF mRNA and protein after LC, which then lasted up to $2 \mathrm{~d}$. In addition, anti-NGF antibody reversed mechanical hyperalgesia. IL-1 $\beta$, IL-6, and TNF- $\alpha$ mRNAs also were upregulated, not only after LC but also after shortening contraction/stretching, but on different time courses. Anti-IL-6 antibody failed to reverse mechanical hyperalgesia after LC. Thus, these cytokines are unlikely to be responsible for mechanical hyperalgesia after LC, and NGF is considered to be the key substance in maintaining DOMS. The time course of NGF upregulation is compatible with the time course of DOMS, and delayed upregulation may explain the delayed appearance of DOMS. The importance of NGF in DOMS is also supported by the absence of upregulation of NGF after shortening contraction and stretching, which do not induce mechanical hyperalgesia. Anti-NGF antibody injected $6 \mathrm{~h}$ after LC completely blocked DOMS. Since the bradykinin released during exercise had already initiated the DOMS process $6 \mathrm{~h}$ after LC and the biological half-life of the antibody is reported to be several days (Shelton et al., 2005), NGF antibody might have continuously reversed DOMS rather than suppressing initiation of the processes that led to DOMS. Only $10 \mu \mathrm{g}$ of anti-NGF antibody was needed to suppress DOMS with an early injection (at $6 \mathrm{~h}$ after LC), but $30 \mu \mathrm{g}$ was needed with later injection ( $10 \mu \mathrm{g}$ was ineffective) (Fig. 6B, left). The early injection might have suppressed NGF-induced NGF release, as reported in mast cells (Mazurek et al., 1986), so that a smaller amount than that used in the later injection was sufficient. In addition, dorsal root ganglion (DRG) and spinal mechanisms also might have been involved in the later phase.

The third finding of this experiment is that $\mathrm{B}_{2}$ antagonist suppressed upregulation of NGF. This observation demonstrated that bradykinin triggers upregulation of NGF through $\mathrm{B}_{2}$ receptors. However, we failed to reproduce DOMS solely by injecting bradykinin into the muscle, and we needed additional shortening contraction to induce muscular mechanical hyperalgesia for $2 \mathrm{~d}$ and upregulation of NGF mRNA. Mechanical hyperalgesia for $1 \mathrm{~d}$ after PBS plus shortening contraction might have been produced by inflammatory mediators other than NGF that were induced by inserting injection needles, since NGF mRNA upregulation was not observed $12 \mathrm{~h}$ after injection. Thus, these data suggest that bradykinin is essential, though not satisfactory, to induce NGF upregulation and lasting mechanical hyperalgesia after LC.

It is well known that inflammatory cells such as macrophages and mast cells produce NGF (Woolf et al., 1996). However, these cells cannot be responsible for NGF production because they did not infiltrate the exercised muscle in this model (Fujii et al., 2008). Since myocytes express $B_{2}$ receptors (Figueroa et al., 1996; 
Rabito et al., 1996) and can produce NGF (Turrini et al., 2002; Toti et al., 2003), myocytes themselves might produce NGF in this model. This point needs to be clarified. The intracellular mechanisms through which bradykinin induces NGF production also need to be clarified. NGF upregulation might be mediated by nuclear factor (NF) $-\kappa \mathrm{B}$ because $\mathrm{B}_{2}$ receptor activated NF- $\kappa \mathrm{B}$ via Ras/Raf/ERK (extracellular signal-regulated kinase) pathway in human airway epithelial cells (Chen et al., 2004) and in fibroblasts (Pan et al., 1996; Lee et al., 2008).

We also showed that rat NGF induced mechanical hyperalgesia and sensitized muscular thin-fiber afferents (majority were C-fibers) in rats. A previous report already showed a hyperalgesic effect and sensitization of A-delta fiber afferents in rats by human NGF, but not by rat NGF (Mann et al., 2006). The reason Mann et al. (2006) did not see any effect with rat NGF is not clear. Hoheisel et al. (2005) showed excitation by NGF in high-threshold mechanoreceptors, but failed to show mechanical sensitization. The observation period (up to $15 \mathrm{~min}$ ) might have been too short to detect sensitization.

NGF is known to induce hyperalgesia in a short period by peripherally sensitizing nociceptors (Lewin et al., 1993; Pezet and McMahon, 2006) and also later by changing expression of neurotransmitter/modulators and ion channels in DRGs (Leslie et al., 1995; Fjell et al., 1999; Mamet et al., 2002; Obata et al., 2005; Zhang et al., 2005; Pezet and McMahon, 2006). Heat hyperalgesia appears rapidly, and thus might be induced by transient receptor potential vanilloid subfamily member 1 (TRPV1) sensitization (Shu and Mendell, 1999) and/or their rapid trafficking to the surface membrane of nociceptors (Zhang et al., 2005). NGF also caused mechanical hyperalgesia, although after a longer latency than heat hyperalgesia (Lewin et al., 1993). Receptors/channels are upregulated by NGF transported to DRGs, and then are orthogradely transported to central and peripheral afferent terminals, where at the latter they play some role in sensitization of nociceptors. This mechanism might be involved in mechanical hyperalgesia after LC in the later phase. However, the quick reversal of LC-induced mechanical hyperalgesia in 3-4 h after antibody injection and quick sensitization of muscular nociceptor responses to mechanical stimulation by NGF in vitro in 10-20 min suggest that NGF also sensitizes nociceptors to mechanical stimulation peripherally without processes in DRGs. This might be induced by modifying actions of TRP channels and acid-sensing ion channels, considering the report of Fujii et al. (2008) that showed antagonists for these channels reversed DOMS.

The appearance of cytokines in plasma or in the tissues (e.g., nerves, muscles, and bones) has been reported in work-related musculoskeletal disorders in humans (Carp et al., 2007) and in animal models (Barbe et al., 2003). However, the causal relationships among cytokines, pain, and other changes have not been analyzed. As to the role of cytokines, Dina et al. (2008) reported an interesting mechanism in which IL-6, after acutely inducing mechanical hyperalgesia, primes later prolongation of muscle mechanical hyperalgesia induced by another agent. In our present results, upregulation of IL-6 was observed at some time points, but anti-IL-6 antibody failed to reverse the developed mechanical hyperalgesia after LC. Thus, IL-6 cannot be responsible for maintaining mechanical hyperalgesia in our model. Whether the priming effect of IL- 6 reported by Dina et al. (2008) exists in this model is not known, but it is known that DOMS becomes less severe or does not occur when LC is repeated after some interval (adaptation) (Clarkson et al., 1987).

In the present experiment, DOMS was reversed by injecting anti-NGF antibody into the muscle in a short period and NGFsensitized nociceptor responses in the excised preparation. Thus, mechanical hyperalgesia in this model was considered to be of mainly peripheral origin. However, the existence of central sensitization has also been suggested in DOMS (Gibson et al., 2006). Involvement of the descending facilitatory system (Tillu et al., 2008) in long-lasting muscular mechanical hyperalgesia induced by repeated acid injection into the muscle (Sluka et al., 2001), and involvement of NMDA receptors and substance $\mathrm{P}$ receptors in the spinal cord in myositis (Hoheisel et al., 1997) have been suggested. Similar mechanisms might be involved in DOMS.

Conditions with muscular mechanical hyperalgesia, such as myofascial pain syndrome, are quite common in the general population. However, their mechanisms are not well understood and reliable treatments are lacking. Hyperalgesic muscle after LC is reported to contain taut band-like muscle hardening and a sensitive spot (Itoh and Kawakita, 2002; Itoh et al., 2004), which are typical in myofascial pain syndrome (Russell and Bieber, 2006). Thus, the present findings may provide new insight into not only the mechanism of DOMS but also the peripheral mechanism of muscular mechanical hyperalgesia in pathological conditions.

\section{References}

Amano T, Yamakuni T, Okabe N, Sakimura K, Takahashi Y (1991) Production of nerve growth-factor in rat skeletal-muscle. Neurosci Lett 132:5-7. Armstrong RB (1984) Mechanisms of exercise-induced delayed onset muscular soreness. Med Sci Sports Exerc 16:529-538.

Armstrong RB, Ogilvie RW, Schwane JA (1983) Eccentric exercise-induced injury to rat skeletal-muscle. J Appl Physiol 54:80-93.

Baker MD (2005) Protein kinase C mediates up-regulation of tetrodotoxinresistant, persistent $\mathrm{Na}+$ current in rat and mouse sensory neurones. J Physiol 567:851-867.

Bao G, Qadri F, Stauss B, Stauss H, Gohlke P, Unger T (1991) HOE-140, a new highly potent and long-acting bradykinin antagonist in conscious rats. Eur J Pharmacol 200:179-182.

Barbe MF, Barr AE, Gorzelany I, Amin M, Gaughan JP, Safadi FF (2003) Chronic repetitive reaching and grasping results in decreased motor performance and widespread tissue responses in a rat model of MSD. J Orthop Res 21:167-176.

Blais C Jr, Adam A, Massicotte D, Péronnet F (1999) Increase in blood bradykinin concentration after eccentric weight-training exercise in men. J Appl Physiol 87:1197-1201.

Boix F, Rosenborg L, Hilgenfeldt U, Knardahl S (2002) Contraction-related factors affect the concentration of a kallidin-like peptide in rat muscle tissue. J Physiol 544:127-136.

Carp SJ, Barbe MF, Winter KA, Amin M, Barr AE (2007) Inflammatory biomarkers increase with severity of upper-extremity overuse disorders. Clin Sci 112:305-314.

Chen BC, Yu CC, Lei HC, Chang MS, Hsu MJ, Huang CL, Chen MC, Sheu JR, Chen TF, Chen TL, Inoue H, Lin CH (2004) Bradykinin B2 receptor mediates NF-kappa B activation and cyclooxygenase-2 expression via the Ras/Raf1/ERK pathway in human airway epithelial cells. J Immunol 173:5219-5228.

Cheung K, Hume P, Maxwell L (2003) Delayed onset muscle sorenesstreatment strategies and performance factors. Sports Med 33:145-164.

Clarkson PM, Byrnes WC, Gillisson E, Harper E (1987) Adaptation to exercise-induced muscle damage. Clin Sci 73:383-386.

Crameri RM, Aagaard P, Qvortrup K, Langberg H, Olesen J, Kjaer M (2007) Myofibre damage in human skeletal muscle: effects of electrical stimulation versus voluntary contraction. J Physiol 583:365-380.

Dina OA, Green PG, Levine JD (2008) Role of interleukin-6 in chronic muscle hyperalgesic priming. Neuroscience 152:521-525.

Ferreira SH, Lorenzetti BB, Poole S (1993) Bradykinin initiates cytokinemediated inflammatory hyperalgesia. Br J Pharmacol 110:1227-1231.

Figueroa CD, Dietze G, MullerEsterl W (1996) Immunolocalization of bradykinin B-2 receptors on skeletal muscle cells. Diabetes [Suppl] 45:S24-S28.

Fjell J, Cummins TR, Davis BM, Albers KM, Fried K, Waxman SG, Black JA (1999) Sodium channel expression in NGF-overexpressing transgenic mice. J Neurosci Res 57:39-47.

Fox A, Wotherspoon G, McNair K, Hudson L, Patel S, Gentry C, Winter J (2003) Regulation and function of spinal and peripheral neuronal B-1 bradykinin receptors in inflammatory mechanical hyperalgesia. Pain 104:683-691.

Fujii Y, Ozaki N, Taguchi T, Mizumura K, Furukawa K, Sugiura Y (2008) 
TRP channels and ASICs mediate mechanical hyperalgesia in models of inflammatory muscle pain and delayed onset muscle soreness. Pain 140:292-304.

Gibson W, Arendt-Nielsen L, Graven-Nielsen T (2006) Delayed onset muscle soreness at tendon-bone junction and muscle tissue is associated with facilitated referred pain. Exp Brain Res 174:351-360.

Graven-Nielsen T, Arendt-Nielsen L (2003) Induction and assessment of muscle pain, referred pain, and muscular hyperalgesia. Curr Pain Headache Rep 7:443-451.

Hilgenfeldt U, Stannek C, Lukasova M, Schnölzer M, Lewicka S (2005) Rat tissue kallikrein releases a kallidin-like peptide from rat low-molecularweight kininogen. Br J Pharmacol 146:958 -963.

Hock FJ, Wirth K, Albus U, Linz W, Gerhards HJ, Wiemer G, Henke S, Breipohl G, König W, Knolle J (1991) HOE-140 a new potent and long acting bradykinin-antagonist: in vitro studies. Br J Pharmacol 102:769-773.

Hoheisel U, Sander B, Mense S (1997) Myositis-induced functional reorganisation of the rat dorsal horn: effects of spinal superfusion with antagonists to neurokinin and glutamate receptors. Pain 69:219-230.

Hoheisel U, Unger T, Mense S (2005) Excitatory and modulatory effects of inflammatory cytokines and neurotrophins on mechanosensitive group IV muscle afferents in the rat. Pain 114:168-176.

Inoue A, Iwasa M, Nishikura Y, Ogawa S, Nakasuka A, Nakata Y (2006) The long-term exposure of rat cultured dorsal root ganglion cells to bradykinin induced the release of prostaglandin E2 by the activation of cyclooxygenase-2. Neurosci Lett 401:242-247.

Itoh K, Kawakita K (2002) Effect of indomethacin on the development of eccentric exercise-induced localized sensitive region in the fascia of the rabbit. Jpn J Physiol 52:173-180.

Itoh K, Okada K, Kawakita K (2004) A proposed experimental model of myofascial trigger points in human muscle after slow eccentric exercise. Acupunct Med 22:2-13.

Langberg H, Bjørn C, Boushel R, Hellsten Y, Kjaer M (2002) Exercise-induced increase in interstitial bradykinin and adenosine concentrations in skeletal muscle and peritendinous tissue in humans. J Physiol 542:977-983.

Lee CH, Shieh DC, Tzeng CY, Chen CP, Wang SP, Chiu YC, Huang CY, Hsu CJ, Fong YC, Tang CH (2008) Bradykinin-induced IL-6 expression through bradykinin $\mathrm{B} 2$ receptor, phosphollipase $\mathrm{C}$, protein kinase $\mathrm{C}$ delta and NF-kappa B pathway in human synovial fibroblasts. Mol Immunol 45:3693-3702.

Leslie TA, Emson PC, Dowd PM, Woolf CJ (1995) Nerve growth-factor contributes to the up-regulation of growth-associated protein- 43 and preprotachykinin-A messenger RNAs in primary sensory neurons following peripheral inflammation. Neuroscience 67:753-761.

Lewin GR, Mendell LM (1993) Nerve growth factor and nociception. Trends Neurosci 16:353-359.

Lewin GR, Ritter AM, Mendell LM (1993) Nerve growth factor induced hyperalgesia in the neonatal and adult-rat. J Neurosci 13:2136-2148.

Li J, King NC, Sinoway LI (2003) ATP concentrations and muscle tension increase linearly with muscle contraction. J Appl Physiol 95:577-583.

Malm C, Sjödin TL, Sjöberg B, Lenkei R, Renström P, Lundberg IE, Ekblom B (2004) Leukocytes, cytokines, growth factors and hormones in human skeletal muscle and blood after uphill or downhill running. J Physiol 556:983-1000.

Mamet J, Baron A, Lazdunski M, Voilley N (2002) Proinflammatory mediators, stimulators of sensory neuron excitability via the expression of acid-sensing ion channels. J Neurosci 22:10662-10670.

Mann MK, Dong XD, Svensson P, Cairns BE (2006) Influence of intramuscular nerve growth factor injection on the response properties of rat masseter muscle afferent fibers. J Orofac Pain 20:325-336.

Mazurek N, Weskamp G, Erne P, Otten U (1986) Nerve growth-factor induces mast-cell degranulation without changing intracellular calcium levels. FEBS Lett 198:315-320.

Muratani T, Doi Y, Nishimura W, Nishizawa M, Minami T, Ito S (2005) Preemptive analgesia by zaltoprofen that inhibits bradykinin action and cyclooxygenase in a post-operative pain model. Neurosci Res 51:427-433.

Nasu T, Taguchi T, Mizumura K (2010) Persistent deep mechanical hyperalgesia induced by repeated cold stress in rats. Eur J Pain 14:236-244.

Obata K, Katsura H, Mizushima T, Yamanaka H, Kobayashi K, Dai Y, Fukuoka T, Tokunaga A, Tominaga M, Noguchi K (2005) TRPA1 induced in sensory neurons contributes to cold hyperalgesia after inflammation and nerve injury. J Clin Invest 115:2393-2401.
Okamoto H, Yayama K, Shibata H, Nagaoka M, Takano M (1998) Kininogen expression by rat vascular smooth muscle cells: stimulation by lipopolysaccharide and angiotensin II. Biochim Biophys Acta 1404:329-337.

Pan ZK, Zuraw BL, Lung CC, Prossnitz ER, Browning DD, Ye RD (1996) Bradykinin stimulates NF-kappa B activation and interleukin 1 beta gene expression in cultured human fibroblasts. J Clin Invest 98:2042-2049.

Pezet S, McMahon SB (2006) Neurotrophins: mediators and modulators of pain. Annu Rev Neurosci 29:507-538.

Pyne DB (1994) Exercise-induced muscle damage and inflammation: a review. Aust J Sci Med Sport 26:49-58.

Rabito SF, Minshall RD, Nakamura F, Wang LX (1996) Bradykinin B-2 receptors on skeletal muscle are coupled to inositol 1,4,5-trisphosphate formation. Diabetes 45:S29-S33.

Russell IJ, Bieber CS (2006) Myofascial pain and fibromyalgia syndrome. In: Textbook of pain, Ed 5 (Mcmahon SB, Koltzenburg M, eds), pp 669-681. Amsterdam: Elsevier/Churchill/Livingstone.

Shelton DL, Zeller J, Ho WH, Pons J, Rosenthal A (2005) Nerve growth factor mediates hyperalgesia and cachexia in auto-immune arthritis. Pain 116:8-16.

Shu X, Mendell LM (1999) Nerve growth factor acutely sensitizes the response of adult rat sensory neurons to capsaicin. Neurosci Lett 274:159-162.

Sluka KA, Kalra A, Moore SA (2001) Unilateral intramuscular injections of acidic saline produce a bilateral, long-lasting hyperalgesia. Muscle Nerve 24:37-46.

Smith LL (1991) Acute-inflammation-the underlying mechanism in delayed onset muscle soreness. Med Sci Sports Exerc 23:542-551.

Summer GJ, Romero-Sandoval EA, Bogen O, Dina OA, Khasar SG, Levine JD (2008) Proinflammatory cytokines mediating burn-injury pain. Pain 135:98-107.

Svensson P, Cairns BE, Wang K, Arendt-Nielsen L (2003) Injection of nerve growth factor into human masseter muscle evokes longlasting mechanical allodynia and hyperalgesia. Pain 104:241-247.

Taguchi T, Kishikawa H, Motoshima H, Sakai K, Nishiyama T, Yoshizato K, Shirakami A, Toyonaga T, Shirontani T, Araki E, Shichiri M (2000) Involvement of bradykinin in acute exercise-induced increase of glucose uptake and GLUT-4 translocation in skeletal muscle: studies in normal and diabetic humans and rats. Metabolism 49:920-930.

Taguchi T, Matsuda T, Tamura R, Sato J, Mizumura K (2005a) Muscular mechanical hyperalgesia revealed by behavioural pain test and c-Fos expression in the spinal dorsal horn after eccentric contraction in rats. J Physiol 564:259-268.

Taguchi T, Sato J, Mizumura K (2005b) Augmented mechanical response of muscle thin-fiber sensory receptors recorded from rat muscle-nerve preparations in vitro after eccentric contraction. J Neurophysiol 94:2822-2831.

Takahashi K, Taguchi T, Itoh K, Okada K, Kawakita K, Mizumura K (2005) Influence of surface anesthesia on the pressure pain threshold measured with different-sized probes. Somatosens Mot Res 22:299-305.

Takano M, Sakanaka F, Yayama K, Okamoto H (2000) Tissue-specific expression of rat kininogen mRNAs. Biol Pharm Bull 23:1239-1242.

Tegeder L, Zimmermann J, Meller ST, Geisslinger G (2002) Release of algesic substances in human experimental muscle pain. Inflamm Res 51:393-402.

Tillu DV, Gebhart GF, Sluka KA (2008) Descending facilitatory pathways from the RVM initiate and maintain bilateral hyperalgesia after muscle insult. Pain 136:331-339.

Toti P, Villanova M, Vatti R, Schuerfeld K, Stumpo M, Barbagli L, Malandrini A, Costantini M (2003) Nerve growth factor expression in human dystrophic muscles. Muscle Nerve 27:370-373.

Turrini P, Gaetano C, Antonelli A, Capogrossi MC, Aloe L (2002) Nerve growth factor induces angiogenic activity in a mouse model of hindlimb ischemia. Neurosci Lett 323:109-112.

Wirth K, Breipohl G, Stechl J, Knolle J, Henke S, Schölkens B (1991) DesArg9D-Arg[Hyp3,Thi5,D-Tic7,Oic8] bradykinin (desArg10-[Hoe140]) is a potent bradykinin B1 receptor antagonist. Eur J Pharmacol 205:217-218.

Woolf CJ, Safieh-Garabedian B, Ma QP, Crilly P, Winter J (1994) Nerve growth factor contributes to the generation of inflammatory sensory hypersensitivity. Neuroscience 62:327-331.

Woolf CJ, Ma QP, Allchorne A, Poole S (1996) Peripheral cell types contributing to the hyperalgesic action of nerve growth factor in inflammation. J Neurosci 16:2716-2723.

Zhang X, Huang J, McNaughton PA (2005) NGF rapidly increases membrane expression of TRPV1 heat-gated ion channels. EMBO J 24:4211-4223. 